\title{
British Paediatric Association Diamond Jubilee Service
}

The British Paediatric Association celebrated its Diamond Jubilee with a service of thanksgiving in Westminster Abbey on 12 October 1988. The Right Reverend and Right Honourable Lord Coggan, a former Archbishop of Canterbury, gave a very moving address with messages that are pertinent to us all. He has kindly consented to the reproduction of the following extracts in order that others may share his words and thoughts.

If I were a parish priest-and after all, they do the basic work of the Church's ministry while we bishops get all the publicity and the brickbats!-I would want to have a staff meeting which met regularly. By staff, I would have in mind not only my curate, church wardens, and organist. I would want the local policeman, school teacher, welfare officer and-yes-perhaps most important of all, the local general practitioner. Why? Because we are, everyone of us, clergy and these experts in their various fields, all engaged on one great task-the health, wholeness, and holiness of the community. How better can that be put than it was in your fine book Child Health in a Changing Society: 'Health is well-being in its widest sense; disease is deviation . . . from that optimum state'. Only when our skills are combined can a proper local health operation be launched and carried through.

This evening, at Marylebone Parish Church, they are dedicating to the service of God and of his people a healing and counselling centre. It is the result of a remarkable vision. The huge crypt of that church, hitherto used as a burial place, has been turned into a very lively place where the healing ministry of the Church joins hands with the practitioners of the various branches of medicine-Harley Street is just nearby - and with the healing forces of music - the Royal College of Music is a stone's throw away. In recent decades, the Church has been reawakening to her original commission to heal the sick. She obeys that commission not in opposition to or in competition with the scientists and doctors who steadily pursue their skilled professions, but in closest cooperation with them, seeing their expertise as a gift from God the Lord of all life.

When we have a child before us-you in your clinic or surgery, or the priest in his study or vestry-we are concerned with that child's total welfare, his 'wholeness'. He may have some deficiency which can be easily remedied, some accident the results of which can soon be put right. But, on the other hand, he may be, so far as we can detect, physically well-and yet not be whole. Concealed behind that brave exterior may be a distorted mind, a wounded spirit, a twisted personality, and we are concerned with the total welfare of the person.

We recognise the damage which comes to a child when he is born into poverty, with inadequate nourishment, with insanitary conditions, with overcrowding and little opportunity for sport. There are pockets of these things even yet in our society. But at the other end of the social scale, there can also be starvation, a starvation of love, of parental supervision and expenditure of time with the child, and the presence of an atmosphere which says 'Money and success are all that matters. Go for your rights and you can forget your duties. Look after number one and forget about God and neighbour'. Where children are brought up in homes like these, damage is done to their wholeness which often proves irreparable.

My own doctor, who has great experience in dealing with schoolchildren, recently emphasised to me the importance of listening, and listening patiently, to the child before him. He must not be fobbed off with a bottle of medicine. He has a burden on his mind which, perhaps, he finds it difficult to express; and, however hard it must be when there are others waiting for our attention, that child must be given the chance to get his burden off his chest and have the privilege of a listening and understanding ear. We need an army of listeners. 